\title{
Replication of Rat Coronavirus in a Rat Cell Line, LBC
}

\author{
Briei Report
}

\author{
By \\ N. Hirano ${ }^{1}$, K. Ono, Y. Sada ${ }^{1}$, A. Inove ${ }^{1}$, T. Murakami ${ }^{1}$, \\ and H. TAKAMARU ${ }^{2}$ \\ 1 Department of Veterinary Microbiology, Iwate University, \\ Morioka, and \\ 2 Department of Bacteriology, Iwate Medical University, \\ Morioka, Japan \\ With 3 Figures
}

Accepted January 16, 1985

\section{Summary}

Rat coronavirus readily propagated and induced marked cytopathic effect in a rat cell line, LBC cell culture, which provided a sensitive, practical assay system for viral infectivity and neutralizing antibody, and a satisfactory source of the virus.

PARKER et al. (4) have isolated an agent with characteristic morphology of coronavirus (5) from the lung of rats. This rat colony was positive for complement fixing antibody against mouse hepatitis virus (MHV). The agent, designated as rat coronavirus (RCV), was shown to share common antigen(s) with MHV. By intranasal inoculation with RCV, a fatal pneumonitis was produced in newborn rats. The growth of RCV has been reported on a primary rat kidney cell culture but not on any established cell lines. Because of the lack of the susceptible cell lines for RCV, consistent work with RCV still remain difficult. This brief communication recommends a rat cell line, LBC, providing propagation of RCV and useful tool for infectivity assay.

RCV, strain 8190 , was kindly supplied by Dr. J. C. Parker, Microbiological Associates, Bethesda, Maryland, U.S.A. The LBC cell line was established in 1983 by Dr. K. Kai, Institute of Medical Science, University of Tokyo, from a spontaneous mammary tumor occurring in a Lewis rat by con- 
ventional methods. Further details of this cell line are still under investigation. The $\mathrm{LBC}$ cells were grown at $37^{\circ} \mathrm{C}$ in Eagle's minimum essential medium (MEM) containing 10 per cent fetal calf serum (FCS) and kanamycin $(0.06 \mathrm{mg} / \mathrm{ml})$. The FCS concentration was reduced to 5 per cent for maintaining the cells or harvesting the virus. Cells grown in $50 \mathrm{ml}$ culture bottles were washed once with Dulbecco's phosphate buffered saline pH 7.2 (PBS), and inoculated with $0.2 \mathrm{ml}$ of virus material. After virus adsorption at $37^{\circ} \mathrm{C}$ for 90 minutes, the inoculated cultures were given maintenance medium and incubated at $37^{\circ} \mathrm{C}$. Cytopathic effect (CPE) was first detected at 48 hours postinoculation (p.i.). At 72 hours p.i. rounding of cells and formation of syncytia developed in the whole cultures, as observed in a primary rat kidney cell culture by PARKiR et al. (4).

Passages of $\mathrm{RCV}$ in the $\mathrm{LBC}$ cell monolayers were readily carried out at intervals of 3 days with undiluted culture fluid. After a few passages, CPE became complete within 48 hours p.i. (Fig. 1). The culture fluid sampled at 48 hours p.i. was assayed for infectivity by inoculating into LBC cells prepared in $13 \times 100 \mathrm{~mm}$ test tubes, showing an infectivity titer of $10^{7.5} 50$ per cent tissue culture infective doses $\left(\mathrm{TCID}_{50}\right) / 0.2 \mathrm{ml}$.

Indirect immunofluorescence and neutralization test were made using anti-RCV rat serum, which was kindly supplied by Dr. J. C. Parker.

Coverslip cultures of $\mathrm{LBC}$ cells were inoculated with the virus, fixed at 24 hours p.i. with cold acetone and subjected to immunofluorescence. The samples were first treated with a 1:20 dilution of the rat antiserum in PBS and then with a 1:20 dilution of fluorescein isothiocyanate-conjugated anti-rat IgG rabbit serum (Miles Biochemicals, U.S.A.) in PBS, respective$\mathrm{ly}$, at $37^{\circ} \mathrm{C}$ for 60 minutes. The virus specific antigen was found abundantly in the cytoplasm of mono- as well as multi-nucleated cells, as shown in Fig. 2.

Serial 2 -fold dilution of the antiserum in MEM were mixed with an equal volume of virus material $\left(300 \mathrm{TCID}_{50} / 0.2 \mathrm{ml}\right.$ ) and incubated at $37^{\circ} \mathrm{C}$ for 60 minutes. Then, $0.2 \mathrm{ml}$ of the mixtures were assayed for CPE by inoculation into LBC cells prepared in test tubes. The antiserum was able to neutralize the LBC-passaged virus showing an antibody titer of 1:640. As control, the titer of rat serum derived from RCV-free colony was within $1: 10$.

The supernatant of infected culture fluid was observed by electron microscopy (Hitachi $\mathrm{H}-600 \mathrm{~A}$ ) after negative staining with 1 per cent phosphotungstic acid. Numerous spherical particles 130 to $160 \mathrm{~nm}$ in diameter with characteristic peplomers were observed as shown in Fig. 3.

The LBC cells can be readily grown in vitro without risk of contamination with latent rat viruses from primary cultures, and are very sensitive to $\mathrm{RCV}$, yielding higher titered viruses compared with the previously described cell system (4). The LBC cell culture might be a much more useful tool for RCV propagation and assay. 


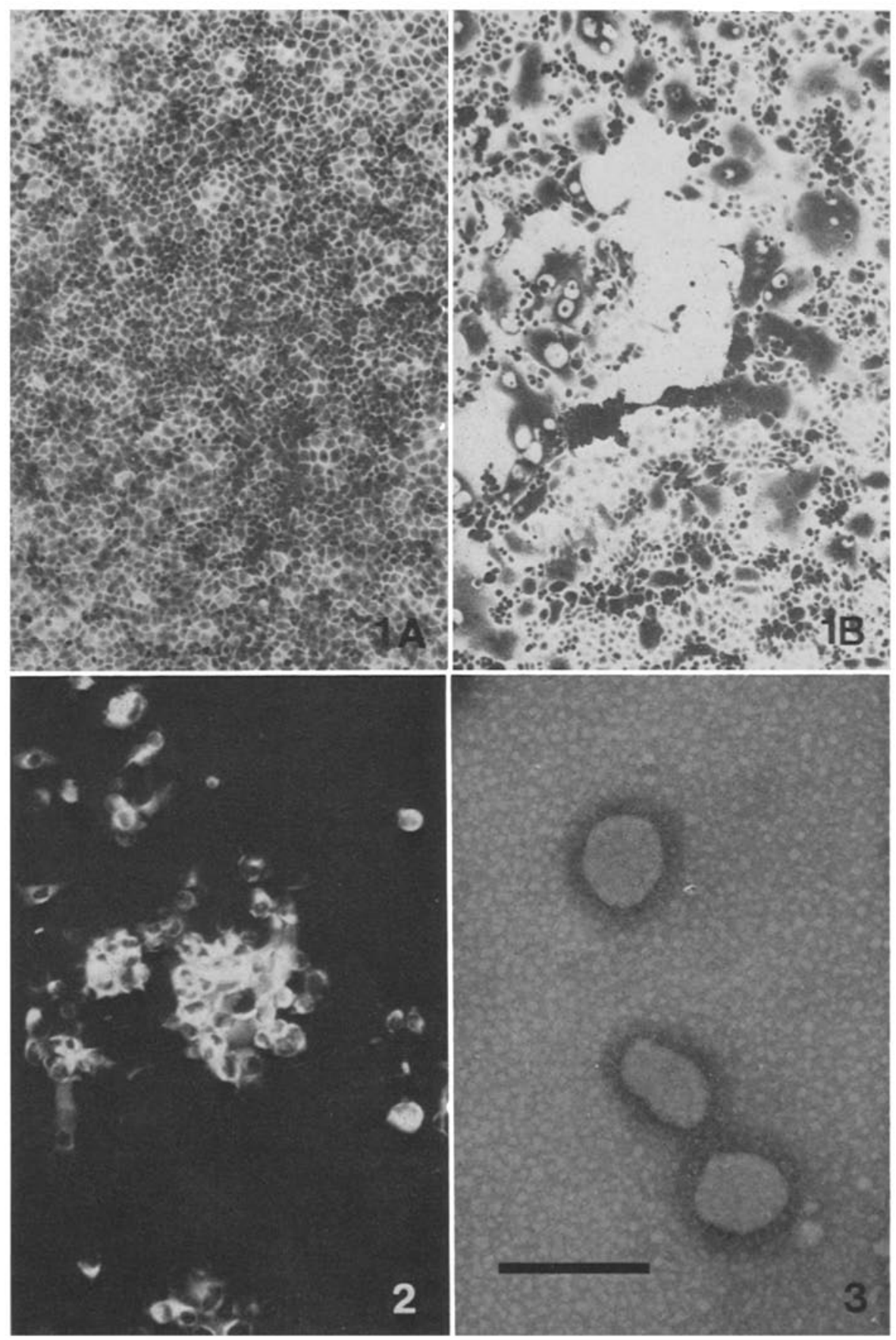

Fig. 1. Cytopathic effect of rat coronavirus in LBC cell culture (hematoxylin and eosin stained). Cells uninfected $(A)$, and 48 hours after infection with the virus $(B)$ Fig. 2. Immunofluorescence of LBC cells 24 hours after inoculation with rat coronavirus

Fig. 3. Negatively stained virus particles from the infected culture fluid of LBC cells $(\times 100,000)$. Bar indicates $200 \mathrm{~nm}$ 
The DBT cell line yielding high-titered MHV $(2,3)$ is not able to support growth of RCV. The LBC cells can also support growth of sialodacryoadenitis virus of rat, strain 681 (1), but not of MHV strains (unpublished observation).

\section{Acknowledgements}

The authors thank Dr. K. Kai for kindly supplying the LBC cells.

This study was supported by Grants-in-Aid for Scientific Research (59360041) from Ministry of Education, Science and Culture of Japan and Naito Foundation.

\section{References}

1. Bhatr, P. N., Percy, D. H., Jonas, A. M.: Characterization of the virus of sialodacryoadenitis of rats: a member of the coronavirus group. J. Inf. Dis. 126, $123-130(1972)$.

2. Hirano, N., Fujwara, K., Hino, S., Matumoto, M.: Replication and plaque formation of mouse hepatitis virus (MHV-2) in mouse cell line DBT culture. Arch. ges. Virusforsch. 44, $298-302$ (1974).

3. Hirano, N., Muragami, T., Fujrwara, K., Matumoto, M.: Utility of mouse cell line DBT for propagation and assay of mouse hepatitis virus. Japan. J. exp. Med. 48, $71-75(1978)$.

4. Parker, J. C., Cross, S. S., Rowe, W. P.: Rat coronavirus (RCV): a prevalent, naturally occurring pneumotropie virus of rats. Arch. ges. Virusforseh. 31, 293 -302 (1970).

5. Siddelu, S. G., Anderson, R., Cavanagh, D., Fudrwara, K., Kuenk, H. D., Madnaughton, M. R., Pensaert, M., Stohlman, S. A., Sturman, L., van der ZEIJST, B. A. M.: Coronaviridae. Intervirology 20, 181-189 (1983).

Authors' address: Dr. N. Hrafro, Department of Veterinary Microbiology, Twate University, Morioka 020, Japan.

Received December 12, 1984 